\title{
Money and Currency in African History
}

Jane I. Guyer and Karin Pallaver

To cite this version:

Guyer, Jane I. and Pallaver, Karin, "Money and Currency in African History." In Oxford Research Encyclopaedia of African History, edited by Thomas Spear, 1-28. New York: Oxford University Press, 2018. Online Publication Date: May 2018, DOI: https://doi.org/10.1093/acrefore/9780190277734.013.144.

Reproduced by permission of Oxford University Press 


\section{Oxford Research Encyclopedia of African History}

\section{Money and Currency in African History}

Jane I. Guyer and Karin Pallaver

Subject: Cultural History, Economic History, Political History

Online Publication Date: May 2018 DOI: 10.1093/acrefore/9780190277734.013.144

\section{Summary and Keywords}

African peoples have managed multiple currencies, for all the classic four functions of money, for at least a thousand years: within each society's own circuits, in regional exchange, and across the continent's borders with the rest of the world. Given the materials of some of these currencies, and the general absence of formalized denominations until the colonial period, some early European accounts defined certain transactions as barter. The management of multiplicity is traced through four eras: a) the precolonial period, with some monies locally produced and acquired, and others imported through intercontinental trades, such as the Atlantic slave trade, and eventually under the expansion of capitalism to Africa; b) the colonial period, when precolonial monies, in some places, still circulated with official monies; c) postcolonial national monies for the new African states; and d) the most recent phase of multiplicity in use, due to migration and sales across borders as well as to the use of new technologies, such as mobile money. The management of multiplicity thereby has a long history and continues to be an inventive frontier. History and ethnography meet on common ground to address these dynamics through empirical study of money in practice, and broader scholarship has drawn on a large variety of original sources.

Keywords: multiplicity, local monies, regional trade, transcontinental trade, colonial currencies, independence, informal sector, exchange rates

The goods, concepts, and practices with respect to money, or in some works currency, have a very long and geographically broad history, with varied and shifting meanings, going back at least a millennium in Africa. The specific contribution of African sources, as the field of monetary history has developed, has become an expanded understanding of the empirical intricacy and careful conceptualization of monetary multiplicity: within selfgoverning societies, in their trade networks over time and space, at interfaces with neighboring peoples and with outsiders who brought goods in from other continents to purchase changing commodities in Africa. Then the transactions based on multiplicity were subjected to colonial rule, during which precolonial currencies persisted in some places, for some purposes, but for a limited time. In the postcolonial condition of national 
independence, national currencies took a central role in socioeconomic life. In the present, both people and goods migrate across national borders very frequently and in large numbers, managed not only by formal businesses, but also by the networks of enterprise and connection referred to as the "informal sector."

The creation, deployment, and ongoing dynamics of African monetary history thus center on the themes of multiplicity and exchange rates through phases and modes. In their own varying and shifting ways, under all these conditions, African peoples have managed multiple materials that have mediated the classic four functions of money-medium of exchange, unit of account, means of payment, and store of value-that were not always based on clearly mandated denominations, in stable quantitative relationships. However, neither was this multiplicity completely reducible to the concept of barter, goods for goods, which had been seen in European social evolutionary theory as the first form of exchange. Barter implies that the goods exchanged are all usable for practical purposes, with situation-specific equivalencies, and not primarily as indices of value, having the material and symbolic durability whereby they could persist over time and from hand to hand, in whichever monetary role they fulfilled. In precolonial African societies, certain items mediated particular transactions, or functions, both within their economic, social, and political lives, and at the interface with outsiders, in commodity-specific trade networks, and at particular frontiers. Their deployment was largely, but not always entirely, focused on valuation rather than pragmatic uses to which some were diverted: as ornament or garment, as a source of metals, and, possibly the case with salt-money, as a dietary input. The mutual valuation and principles of bundling were clearly approached from the African side of the bargain, as having currency values beyond the immediate bargain, with much of the received goods syphoned as currencies into their own markets, or deployed as materials for other purposes.

This gives greater prominence to the relevance of understanding the longer historical range, from specific periods of currency history, to current practices, which may find an archive of knowledge in the management of multiplicity in the past. Dealing in multiple currency objects has a deep history in Africa, in its own inventive terms for fostering expertise at the level of the people. Study of the past and current practices in this domain of economic life remains an open frontier for research, alongside detailed understanding of state and international action. Due to the prominence of international trade in the supply of currency goods to Africa, the continent is not marginal to global monetary history, for two reasons: a) it has participated in the world trade of currency goods, and b) it can therefore be an arena for scholarship's extension of the analytics of interfaces and shifts over time, both within and between systems in which the role of monetary authorities was local and specific, rather than national and international, for long periods.

The richness of the topic of money in Africa thereby lies in the empirical methods applied to it, and the findings, through archaeology, the ethnography of crafts, oral histories of local events and processes, linguistic attention to words and numbers, and study of the detailed written records of trade and administration. This variety of sources reflects the complexity and richness of the history of African money, more than any orientation 
toward theoretical engagement with the macro theories of a) the internal evolution of economy and society from subsistence hunting and gathering to settled farming and eventually to greater centralization and hierarchical authority over a money-mediated economic and political life, and b) the externally provoked changes coming from centers of power to peripheries.

In the first section, the classic referents of monetary multiplicity in the study of African currency systems are addressed briefly. The second section reviews four eras that have been studied in empirical detail: a) the precolonial history of Africa, including the sources on the monies of the slave trade along the West, Central, and East African coasts; b) the colonial period, during which the coexistence of indigenous and colonial monies comes to the fore; c) the period after decolonization, when independent African countries adopted new national currencies; and finally d) the present era of multiple national and international currencies, used in the growing and diverse urban informal sector, artisanal mining, links to international trade, migration, remittances, suspicion of counterfeiting, and new technologies. Each of these four eras in the second section prioritizes the terms under which monetary multiplicity has been managed in Africa.

\section{Multiplicity in the Study of African Currency Systems}

The question of how, and in what exact terms of mutual reference, multiplicity in monies is produced, named, and managed is a very complex question, especially where the deployment of the monetary materials crosses boundaries that are both external to particular systems, and internal to each system's domains of money-mediation, as they have always done in Africa.

Africa's experimentation with monetary mediations extends at least from the 1st millennium, when its gold infused the growing state-run monetary systems of the Mediterranean world. Soon thereafter, cowries were imported to West Africa via land from the Maldive Islands and later became one of the currencies of the slave trade, augmented by copper manillas (bracelets), iron bars, textiles, glass beads, liquors, and other imported objects. Many of these currencies circulated together and often performed different functions. In Africa, over centuries of long-distance trade, the regional markets and local culturally based social transactions were mediated through many value-calculable objects: some imported through trade and others produced by local artisans. The management of what we would now refer to as "exchange rates" between systems, such as across cultural borders along commodity-specific networks, was generally localized to particular frontiers, at the interface of different economic and value systems. 
Under colonial rule, the precolonial currencies, both locally made and traded and brought in through the European and Indian Ocean trades, still circulated locally alongside colonial money, until they were gradually de-monetized and withdrawn from circulation by the colonial governments. Previous to these withdrawals and the postcolonial situation, there were no systems in which all the monetary objects in circulation were issued, mandated in their quantitative terms of mutual equivalence, and disciplined in circulation, by centralized monetary authorities alone. Merchants and the market itself organized what was an "assortment of currencies."

Therefore, "multiplicity" can be used in the study of the history of money in Africa in all the senses through which it has been conceptualized and realized in monetary systems, with the African experience seen as being both a participant in larger systemic networks over time and a source of its own originality: in materials, transactions, stores of wealth, and proverbial referents. Most recently, with the globalization of trade and the rising rates of migration, many multiple currencies continue to circulate within Africa.

One aspect of the history of the management of multiplicity is local expertise on the currency materials and their genuineness. Two brief examples can illustrate that such expertise and selective adjudication have a long history. In the 19th century, there is a reference in a history of manilla production in Birmingham to a West African "sable mintmaster," whose population sent him to England to check on the quality of their manillas, which they suspected, correctly, to be inferior by virtue of being made of iron coated with copper rather than being made of genuine brass. ${ }^{1}$ There has been a money-changing system in the Sabo quarter of Ibadan, Nigeria, passed down in families over generations, for at least a century, if not longer. Visiting an elderly money-changing expert in his shop in Sabo in the 1990s, Jane Guyer asked him about the recognition of counterfeits, and he held a paper bill up to his ear and crumpled it, thereby testing its tangible and auditory qualities. He reported that he had learned recognition techniques from his family forebears in the business.

Given this history, the African people's experience in dealing with multiple currencies is both a continuing challenge for research within Africa and her diaspora, and a source of empirical and conceptual richness for application beyond its own peoples and borders. Historians and political economists have contributed to the interdisciplinary enrichment on this topic, while anthropologists have contributed many local studies, people's own concepts and practices, and their own analytics to the understanding of conceptual and practical instances of money management by the people under varied and changing circumstances. A complex and shifting history of multiplicity can be compiled through the many sources we have, from trade records in European languages, oral-historical accounts, ethnography, and increasing attention to the place of Africa in the multiple currencies and interconnected world of the past several decades. 


\section{Historical Phases of African Money}

\section{The Precolonial History of African Money}

\section{Regional Trades and Exports in West African Early History}

Africa's own material objects, used for the classic four functions of money in the precolonial period in trade within the continent, had two main sources: local materials such as copper, iron, and salt, which were crafted into forms for circulation, and imported items from trade across the Indian and Atlantic Oceans, and from the Mediterranean. Over at least a millennium of the development of local markets, long-distance trade within the continent, and intercontinental trade across the oceans, Africans developed monies without the kind of state-level control over its making and use that was characteristic of Europe: political institutions, groups of merchants, and the market itself created the assortment of monies used in local, regional, and international trade.

The oldest export from Africa in the sphere of money was gold traded into the Mediterranean world. As depicted by Bovill in his The Golden Trade of the Moors, West African gold was traded to several ports on the coast. ${ }^{2}$ Across West Africa and along trans-Saharan trails, the gold mithqäl was used as a standard measure to weigh gold dust. Miqthāl, from the Arabic "weight," was 0.25 ounces and was a fairly stable measure in the markets of Africa and the Middle East. ${ }^{3}$ Gold was used in international trade, and saltbars in regional trade. Salt was a commodity, but in certain times and places, bars of salt functioned on a negotiated exchange rate with other currencies, even though the ultimate purpose of its acquisition, in some places, might be for consumption. According to Ibn Batutta, in the 14th century, "At Walata a load of salt brings eight to ten mith qals (half an ounce of gold) ... The Negroes use salt as a medium of exchange, just as gold and silver is used (elsewhere); they cut it into pieces and buy and sell with it." 4

Imported cloth also functioned as currency in Saharan and West African exchange. Cotton currency or baysa, named in French pièce de guinée, was a standard unit of cloth 15 meters in length and 1.5 meters wide. Different varieties of cotton currency were in use, and by the late 18th century, the baysa had become an "interface currency" used as "the standard unit of account for market transactions, taxation rates and property rights." 5

Cowry shells originating from the Indian Ocean (Cypraea moneta) were also part of West African currency systems. The earliest cowry currency area was the upper and middle Niger. By the 14th century, the area extended to the Mali Empire and later to Timbuktu, Jenne, and probably the Bambara country by the 16 th century. ${ }^{6}$ Cowry shells found such use as currency because they were durable objects, almost impossible to counterfeit, and they were homogeneous and had a very low unit value. For these reasons, being already 
in use in West Africa at the time of the development of transatlantic trade, they later became the "shell money of the slave trade."7

\section{Money and Political Power in Precolonial Africa}

In centralized polities, historians have explored examples of the relationship between money use and power in precolonial Africa. African political institutions could control the circulation and use of currencies, by imposing the payment of taxes in a specific currency rather than in kind, restricting the amount of currency in circulation or fixing the price of goods in commodity currencies.

In 17th- to 18th-century Central Africa, in the Kuba kingdom located in what is now the Democratic Republic of the Congo, central control was crucial to the money system. Here two currencies were in circulation within the kingdom: cowries and raffia cloth. Nzimbu shells, instead, mediated trade along one of the trade routes that ran through their territory, but were not accepted as currency by the Kuba themselves. Functionaries of the king operated in both spheres and controlled the trade in shells; they based their general affluence on their role as middlemen. This position could be held only by military power. ${ }^{8}$

A comparably centralized polity was the Ashanti kingdom, in what is now Ghana, where gold was both a product for trade and a medium of exchange. ${ }^{9}$ The weighing of gold dust, as a currency, through the arts of the gold weight system, is a topic approachable through the museum collections of the figurines used as measures. ${ }^{10}$ The weights were not standardized by central authorities, and indeed one possible inference is that each trader's figure met with their counterpart's figure and offered, together, a proverbial or conversational memory of the transaction. Centralized control ran through other channels. Kwame Arhin has argued that, in the 17th century, the gold trade was the "lever of power for the budding Akan kingdoms," and gold dust was the medium for taxation, tribute, and fines, as well as for internal and external trading. The Ashanti kingdom's wealth in gold dust supported its military power and the political control of the region. ${ }^{11}$ It was the colonial regime that abolished the traditional fiscal constraints on the private acquisition of wealth. ${ }^{12}$

Another further example is the kingdom of Buganda. The information we have on the currencies in use there before the arrival of coastal traders in the 19th century is fragmentary. It is likely that the first item to function as currency was barkcloth. People generally exchanged goods in non-monetary transactions, but when high-valued items like hoes, goats, or cows changed hands, they were priced in barkcloth. ${ }^{13}$ Tributes to the king - the kabaka-were also paid in barkcloth, which was specifically made for this purpose and, together with other products like beer or fowl, was part of marriage payments. ${ }^{14}$ In the second half of the 18 th century, ensinda beads started to come into circulation and were gradually used as currency. The kabaka had a monopoly on the circulation of ensinda, and they were used for trade purposes as well as to pay taxes to the king. At the end of the century, beads circulated together with ivory pieces, which gradually replaced beads. These pieces came in the form of smooth and light bored discs, which were put on strings made of palmfiber. Specialists in the royal palace carved these 
ivory discs, and the king controled the quantities in circulation. ${ }^{15}$ In the first half of the 19th century, long-distance trade goods like cowries and imported cloth were introduced in Buganda by coastal traders following the growth of international demand for ivory and slaves. The circulation and acceptance of cowries were favored by the kabaka, who fixed the price of goods on sale in the capital's market and imposed the use of cowries in the payment of fees and taxes. ${ }^{16}$ Recurrent currency changes were therefore endemic in precolonial African societies, and monetary developments usually reflected broader trends of commercial expansion. ${ }^{17}$

The connection between political power and money in precolonial Africa is also testified by African political institutions that issued their own coins. The earliest example of coins minted in Africa comes from the kingdom of Axum, which struck money from the 3rd until the 8th century CE. ${ }^{18}$ In the 8th century CE, the Swahili sultanates of the East African coast also started to mint their own coins. The biggest part of the coins excavated by archaeologists along the coast are copper coins produced in the town of Kilwa. Copper was a valuable metal in East Africa and could be easily obtained in order to produce coins. The circulation of Kilwa copper coins was limited, and they seem to not have filtered into Indian Ocean markets in significant quantities. This points toward a local use and is a clear indication of the connection between these coins and the authority of specific rulers, rather than to a universal standard of value. ${ }^{19}$ Swahili coins were part of a complex monetary system characterized by the simultaneous circulation and acceptance of commodity currencies, such as beads, cloth, and grains. ${ }^{20}$ Minting on the Swahili coast lasted until the 15th century, when the arrival of European traders promoted the use of international coins, such as Spanish piasters and Maria Theresa thalers. These international-trade coins did not have subsidiary coins, and locally minted smalldenomination coins circulated in some towns along the coast, such as in Mombasa and Lamu. However, owing to the general lack of small-denomination coins in the coastal markets, broken sums were generally paid in sorghum, of which exceedingly variable measures constituted the thaler. The simultaneous circulation of coins and commodity currencies characterized therefore the history of the Swahili world. These currencies were objects that performed both monetary and symbolic functions. The value attributed to them was related to their exchange use, but also to the ways in which these objects were displayed and employed in ritual and cultural spheres. ${ }^{21}$

\section{International Transactions: The Monies of the Slave Trade}

European materials and concepts came into the African monetary world through the slave trade. These objects had an intrinsic value that went beyond their exchangeability. Cloth was used to make clothes, glass beads and cowry shells were largely employed to make ornaments and in rituals, metals were melted down to make tools, and so on. Scholarship on the precolonial centuries of African monies is richest for details of quantified transactions with respect to the international trades, especially the slave trade, since many transactions were documented in writing, whereas the trades internal to the continent have left patchy records in some places and oral histories in others.

Page 7 of 29

PRINTED FROM the OXFORD RESEARCH ENCYCLOPEDIA, AFRICAN HISTORY (africanhistory.oxfordre.com). (c) Oxford University Press USA, 2016. All Rights Reserved. Personal use only; commercial use is strictly prohibited (for details see Privacy Policy and Legal Notice). 
Assortments of cheaper and more expensive goods entered the trade from the European side and were used for bargaining. The "trade ounce" was an attempt to introduce a standard unit of value on the 18th-century Guinea coast and was conceptually based on gold, but not necessarily mediated in gold. A "trade ounce" was the quantity of trade goods that could be exchanged on the Gold Coast for the equivalent of one ounce of gold. Karl Polanyi wrote on "sortings and the ounce trade," which Marion Johnson then took further to show how the concepts, materials, and exchange rates emerged and changed over time, producing an elaborate system of equivalences. ${ }^{22}$ She offers detailed examples of assortment of goods (cloth, metal pans, guns, gunpowder, rum, etc.); their cost at source in pounds, shillings, and pence; and their value in the purchase of a slave on the Gold Coast and at Whydah. In the 1760s and 1770s, African sellers demanded gold in payment of slaves, because gold was no longer exported from the Gold Coast. As a consequence, an ounce of gold was valued at two ounces of trade goods. ${ }^{23}$ Through these negotiations of assortments and standards, pegged implicitly and sometimes with a material manifestation to the gold ounce, the Atlantic slave trade brought more and more material items into the monetary valuation system of West Africa. Cowry shells became one of the items more in demand across West Africa. The first historical evidence of the use of cowries in the purchase of slaves dates back to the first half of the 15th century. The increase in the number of slaves exported corresponded to a peak of the cowry imports in the 18 th century. ${ }^{24}$ The cowry currency was nonconvertible, and therefore all the shells entering West Africa remained there, testifying to the expansion of the area in which cowries were used. ${ }^{25}$

Claudia Zaslavsky offers a history of cowry equivalences, numerated, with their nomenclature in African languages. The actual numbers in each grouping varied across time and space, and she offers the gold equivalents to numbers of cowries in Muslim hundreds, Bambara hundreds, Mandingo hundreds and strings (on the coast), and the Igbo terms for money numbers. It is likely that these variable numbers allowed a trader to break down bundles, rename them, and thereby sell the whole amount at a considerably higher price that he paid for it. Profit lay in the naming of the numbers and the detailed calculation that cowry currency allowed, as "the profits were built into the currency system." ${ }^{26}$ In precolonial Buganda, cowries were bored and put on strings of one hundred shells called kiasa. This could be divided into halves of fifty each, and again into five parts of ten each, the smallest division being five shells. This made cowries particularly suitable to buying goods of very small value, like foodstuffs, and at same time allowed for the creation of larger-currency denominations. ${ }^{27}$ Hogendorn and Johnson show how, in terms of cowries per slave, the price in the 1680s ranged from 10,000 to 31,000 , whereas in the 1770 s it ranged from 160,000 to 176,000 per slave. This increase was due to the fact that slaves were coming from farther away and shells had to be paid to sellers of produce along the roads. ${ }^{28}$

Several other works bring the monetary variations and fluctuations of the Atlantic trade into sharp historical relief. Toby Green's work on the 17th century documents the exact inflation rates for certain currencies, such as copper-alloy manillas. In 1500 the price of a slave was $12-15$ copper manillas, then by 1517 this had risen to 57 manillas. ${ }^{29}$ Robin Law 
outlines the place of cowries in the history of Dahomey, and the changing terms for their units of calculation and account from the 18th to the 19th century. He points out that their value in local markets was clearly affected by the wider economic dynamics. He particularly examines the transition from slave trade to palm-oil trade in the export markets, the latter of which was supplied by small producers for whom cowries were the most convenient means of payment, although their increased importation had already led to a decline in their value relative to other international trade measures, such as dollars and British shillings. ${ }^{30}$

Paul Lovejoy has examined a comparable process of cowry diffusions among the states of the Sudan, from the 18th century onward. He points out how the increased use of cowries in the 18th-century Hausa states stimulated the Oyo economy and the Niger River trade and also promoted "the expansion of potash production within Borno's economic sphere, the growth of Hausa textile and leather manufacture, and provided an incentive for increased output of cotton, indigo, onions, and perhaps sheabutter, pepper, and other agricultural goods."31

In East Africa, the huge increase in the demand for East African ivory and slaves that developed in the 19th century produced significant changes in the currency systems. The increasingly systematic connection of the interior regions to the coastal economy resulted in the "commodification" of the local economies through the import of goods that were invested with new exchange value and emerged as currencies to facilitate market transactions. ${ }^{32}$ The use of multiple currencies characterized East African trade networks. The commodities that had been already objects of trade between the coast and the interior such as cloth, glass beads, and cowry shells crystallized into a monetary form and became part of a monetary system characterized by the adoption of standard units of currency. Imported cloth played the most important role in commercial transactions throughout the Zanzibar hinterland as it was the currency generally used to buy ivory and slaves. In the 19th century, imported cloth (mainly of American origin, locally known as merikani) became the most widespread means of accumulating and storing wealth, as its possession was strictly related to political power. African chiefs distributed cloth to their followers as a way to secure loyalty and political support. Imported cloth was also used to pay caravan porters' wages. ${ }^{33}$ In some areas of the Zanzibar commercial hinterland, especially in the interlacustrine region, copper and brass wires were used as an alternative to cloth. Cloth and metal wires were used together with small-denomination currencies, particularly Venetian glass beads and cowry shells. Since beads, as opposed to cloth, could be split up into small units, they became the most widespread means of buying food during caravan journeys. In the markets of the main commercial towns of the interior, such as Msene, Tabora, and Ujiji, a standard currency in beads was adopted in the second part of the 19th century. The rate of exchange was based on a cloth standard, and beads became an interface currency that allowed traders of different origin to meet and exchange their goods. ${ }^{34}$ 
In some places, non-African official currencies circulated along commodity currencies, in multiple, often complementary, relationships. Non-African official currencies were regular-issue coins that often had legal-tender status in their country of origin, but acquired a circulation far beyond their national borders and were accepted depending on recognition, familiarity, and trust. In Nigeria, for example, long before British currency was imposed in Lagos in 1880, "Mexican, Peruvian, Brazilian and Chilean dollars circulated freely alongside British gold, silver and copper coins, Spanish and South American gold doubloons and half doubloons, American double eagles, eagles, half eagles and quarter eagles, French twenty-franc pieces, gold dust and nuggets, and Maldive and Mozambique cowries." 35 Qualitative estimations in exchange contexts, as distinct from either mandated or customary quantitative rates, were important, and just as African currencies had no monetary value in Europe and were generally treated as barter items by Europeans, so also among the African population, British and other European coins had little or no monetary value, and they were accepted only for the bullion value of their metal content. ${ }^{36}$

Akinobu Kuroda has shown that in the Red Sea region and Ethiopia, the coexistence of multiple monies was not incidental but functional, since they worked in a complementary relationship: the Maria Theresa thaler functioned as a buffer between international monetary circuits and local markets where other currencies were used, such as Indian silver rupees, Italian 10-lire notes, salt-bars, and cloth. ${ }^{37}$

The history of precolonial money shows how varied were the objects and their origins and applications that were used to mediate exchanges. The history is long, and the geographical trade networks were wide, so the inventiveness was likely to be recurrent. The actual objects, those made of long-lasting materials, made continuous flow (as medium of exchange) and long-term conservation (as store of value) possible to maintain, even if under varying moral frameworks of spheres of exchange and value. This monetary variety, multiplicity, and range of customary practices at the interfaces, both within societies (in the spheres of exchange mode) and at regional, and other, interfaces, is still a frontier of research to illuminate the ongoing use of these currencies, customs, practices, modes of calculation, and uses of the classic four functions of money, within local transactions. The coexistence in any one society, or region, of different objects serving as currencies, over long periods of trade, made for a richly varied, and shifting, practice in different places and networks. In many places, what would be termed "denominations" in European history (copper, silver, and gold coins) were actually cocirculating objects with their own characteristics, each one functioning in certain particular domains of economic life and regional exchange, generally without central authorities to regulate their equivalences.

Recent historical work has homed in on such intricate empirical topics. It is from these works that the scholarship can focus yet more deeply on the nature of currency interfaces: among different types, for different purposes, and operating within different spheres within particular local economies, and then at the shifting historical frontiers as the encompassing economic dynamics, currency types, and sources of political discipline 
over commerce change over the centuries. Several of these historical works give profile to the processes producing profit: for whom, and by what means. These examples of multiple-currency management within Africa in the past can enrich the conceptual repertoire for the study of the multiplicity of the present.

\section{The Colonial Period: Indigenous and Colonial Currencies in the Transition}

The introduction of new currencies in the colonies was one of the most important institutional changes brought by colonial rule. One of the main goals of the colonial reform of African monetary systems was the reduction of transaction costs between the colony and the home country. At the same time, the introduction of a "modern" currency was seen as a way to transform local economic structures and to construct exportoriented economies. Other reasons were the desire to control macroeconomic conditions in the colonies, and to increase seigniorage revenues, which were seen as a way to finance local colonial governments. Finally, colonial currencies had symbolic value. They were perceived as an instrument that would create a homogenous colonial space and enforce recognition of the authority of the new colonial governments. ${ }^{38}$

The divergence between the specificity of African monetary systems and the European intention of introducing one, single currency in the colonies perpetuated the multiplicity of currency circulation that had characterized the precolonial period. As a consequence, the monetization of the colonial period was not an abrupt change from a customary usage of certain commodity currencies to the coins and notes introduced by the colonial power. Rather, this was a gradual transition, encompassing the coexistence, sometimes for decades, of multiple currencies that had different implications for economic life and social relations.

Allowing the circulation of precolonial currencies was a practical necessity for the colonial state, especially in the early colonial period. It was not possible to introduce enough colonial currencies, and African people working for Europeans often refused to be paid in colonial money. For a limited period of time, taxes were therefore accepted in commodity currencies, and colonial governments tried to control the introduction and circulation of African money. In eastern Nigeria, for example, the British government, unwilling to pay the price for redemption, had to allow the circulation of manillas, because it was impossible for them to introduce enough British currency. The governor of the colony allowed manillas as legal tender in 1902 and claimed the right to set the exchange rate. ${ }^{39}$ British coins circulated for small purchases and imperatively for tax paying, and the manilla began to be stored for symbolic and prestige purposes. From 1900 to 1948 (when manillas were withdrawn), the price of palm oil in shillings and manillas shifted from year to year. The fluctuating prices for their products left the African population with problems of livelihood, and, as Ben Naanen observes, "The ferments generated by fluctuating manilla values have remained, until now, unidentified 
causal links in the political movements in south-eastern Nigeria, including especially the women's movements of the 1920s." 40

Also in southern Nigeria, precolonial and colonial currencies circulated together, and the economy was formed by two currency systems, one based on cowries, and the other on British metal currencies. ${ }^{41}$ Cowry shells were more suitable than British currencies for daily transactions, and as a consequence, local currencies circulated alongside colonial money for fifty years and were replaced only when inflation and the "colonial economic and social revolution could take their toll." ${ }^{42}$ African commodity currencies were often better suited than colonial coins for transactions of very small value. In East Africa, for example, the British tried to mint a coin of one-tenth of a cent, worth as low as an individual cowry. Its actual introduction was however made impossible by the exorbitant costs of minting such a small-value coin in Great Britain and shipping it to East Africa. ${ }^{43}$ As a matter of fact, African commodity currencies were often more suitable than colonial money to circulate in societies with very low prices and incomes.

In other areas of Africa, many of the prestige monies, specialized stores of value that were used for social payments, were much closer to being of long-term use-value as well as exchange value, such as the cattle used for bridewealth (lobola) in southern Africa. Thus could the store-of-value monetary function, that is, money saved and deployed for social-status purposes, be concentrated in a utilitarian good whose value veered toward what modern analysis would define as an "asset." As the colonial presence and its monetary discipline set in, the subject populations all over the continent reassessed their multiple currencies and spheres of exchange from the past.

The imposition of colonial currencies was challenged by African conceptions of value in connection with different types of currency. In French West Africa, for example, different social groups had contrasting attitudes toward the cowry and the colonial franc. The prohibition to import and use cowry shells was introduced in 1907, but it was largely resisted, especially by market women. Colonial coins were refused because they could not be counted and stored as cowry shells, but also because they were the money "of the White man." By refusing to use colonial money other than for paying colonial taxes, people could partly maintain their economic independence. ${ }^{44}$ Currency policies for the colonies were generally designed according to European monetary traditions and conventions. However, local monetary practices often came into conflict with these foreign traditions, and currency policies of the colonial governments had to be adapted to local specificities. In Uganda, for example, at the time of the monetary reform of 1905, the relation of the Indian rupee-the official currency of Kenya and Uganda-to its new subsidiary coins, the East Africa cents, was clearly created according to the relation of the rupee with the cowry. One rupee corresponded to a thousand cowries, fifty cents corresponded to five hundred shells, twenty-five cents to two hundred and fifty shells, ten cents to one hundred shells, five cents to fifty shells, one cent to ten shells, and one-tenth of a cent to one cowry. It is evident that the new monetary system mirrored the existing one based on cowries and was modeled on the way in which shells were counted. At the 
same time, small-denomination coins were minted with a hole in them, so that people, according to the colonial interpretation, could put them on strings as they did with cowry shells. ${ }^{45}$

Another domain in which money circulated in specialized ways under colonial ruledistinct from the payments to the state as taxation, the receipts from the regional and international market for crops, the growth of urban supply markets, and social-status confirmation in the people's own terms-was the world of pilgrimage and religious community. The Muslim centers, and the emergent indigenous religious movements such as Bwiti, described in detail by James Fernandez for the Congo, included moneymanagement systems, as followers crossed colonial boundaries to make pilgrimages and drew on past concepts and practices. ${ }^{46}$ Again, multiple currencies would converge in these regional communities, but not through a systematic layering of the kind and value of the goods, nor the status definition of the participants.

The Congolese Bwiti cult can serve as another religiously infused example of currency use, in this case for what Fernandez depicts as social reciprocities, within a colonial regional system, where incomes from cash crops (cocoa and coffee) were paid in the colonial general-purpose currency, the colonial franc. He notes that the people suffered deep fluctuations in cocoa prices between 1954 and 1955-1956, from 175 francs to 60 francs per kilo, which the villagers saw as a kind of "robbery" perpetrated by the traders. He gives an inventory of incomes in francs (and dollars, according to the exchange rate) for male heads of families and households, and offers that the difficult monetary position of women accounted for their artistic creativity within the Bwiti cult: particularly selling dances. Bride payments augmented in monetary value, paid in colonial francs, although he argues that their real value remained very stable. ${ }^{47}$

Jane and John Comaroff, studying the introduction of banknotes among the Tswana, highlight how colonialism and the process of colonial monetization were also a material process based on a logic of commensuration and conversion among different regimes of value and "semantic frontiers." The physical properties of money objects were important for how equivalences were established. ${ }^{48}$ The relevance of the materiality of money is exemplified by the introduction of paper money in the colonies. Paper money was generally disliked by African traders and laborers, because it could be easily destroyed by fire and insects. Nonetheless, banknotes had to be introduced in the African colonies during and after the First World War, owing to the scarcity of metals needed to mint the coins, and to the naval blockades that hindered the possibility to export coins to the colonies. In French West Africa, for example, during the war paper notes were introduced to replace small-denomination coins. However, these currency notes were regarded with suspicion by laborers, and many refused to work for them. Those workers and soldiers who accepted notes frequently exchanged them for coins with money dealers at a loss. In French West Africa, as well as in the Northern Territories of the Gold Coast, the war caused a return to the use of cowry shells as currency. ${ }^{49}$ 
The symbolism of colonial money is another aspect that had important implications for the relation between the colonial state and African societies. Colonial coins had the portrait of the European rulers on them, and the design of colonial banknotes represented the colonial state, the colonized territory, and the colonial subjects. Wambui Mwangi shows how in 1950s Kenya, the change in the design of paper notes represented a change in the view of the colony at the time of the Mau Mau uprising. The lion and the mountain that had been depicted on East African banknotes were replaced by a "cashcrop iconography." From a natural and distant world, the colony was represented as a site of economic and social progress, in which all the racial components of the colonial society contributed to the development of the colony. This was intimately connected to the need of showing a multiracial colony as a response to the Mau Mau uprising. During the revolt, banknotes were also used to convey political messages. Mwangi reports of a five-shilling note withdrawn and sent to treasury on which someone had written "Mau Mau Very Good." 50

The association of the introduction of colonial money with rationalization was contested by the way in which colonial money was accepted, rejected, transformed, and remembered. In Malawi, the elders interviewed by Amy Kaler considered the introduction of colonial money to be responsible for breaking bonds of respect and honor that had previously structured social and economic relations. Money and cash developed a new importance as a means of marking status in African communities, and changed marriage relations as well as relations between men and women. ${ }^{51} \mathrm{Moral}$ and spiritual sources, brought forward from precolonial to later periods, have been depicted for the Yoruba by Akanmu Adebayo and Toyin Falola when they address the colonial period. They give an account of ten "ideals" to money, which have become popular sayings. The following are the central ideas: 1. Money is "the Indispensable One," "an active participant in human relationships"; 2. "one must have patience to acquire money"; 3. "wealth and age need not correspond"; 4. "money is acquired but wealth is inherited"; 5. "Money is the engine for spreading the gospel," which they illustrate as an idea also prevailing in Islam; 6. "money should be acquired honestly. Otherwise, money will not last"; 7. "Avoid debt," referring to the era of the slave trade when a debtor who failed to repay could be sold by his creditor; 8. "being a person of character is of greater value" than having money, and being one of the "boastful rich"; 9. "money is death, or the reckless search for it could end in death"; and 10. "To be rich is an act of fate or destiny." Adebayo and Falola then show how contradictions among these ideals, still quoted but under changing historical circumstances, are part of the ongoing dynamics of money in Yoruba culture and society. ${ }^{52}$

In another recuperation of past money culture among the Yoruba, Falola demonstrates the complexity of the emergence during the colonial era of individual rights to assets, especially land, in the context of a new organization of debt. Local creditors had relied on "human labor as collateral" in the past, but what counted as an asset moved into new forms: land, wages from a regular job, and other sources that depended on the state legal 
frameworks. ${ }^{53}$ This scholarship, largely by African scholars, shows how aspects of the precolonial cultures of money have been brought forward in time: selectively, and in changing ways depending on the context.

The circulation of colonial money was promoted by the introduction of taxes, the payment of wages in colonial money, and the demonetization of African commodity currencies. Local commodity markets, such as the growing system for urban food supply from the producers in the hinterlands, did include, in some areas, the possibility of paying for everything in colonial currency. ${ }^{54}$ However, the persistence of the circulation of precolonial currencies in the colonial period suggests the continuing relevance of autonomous economic and social spaces that contradicted the colonial intention of achieving a stable and consistent circulation of its currency in the colonial space. ${ }^{55}$

By the time of its passage of power, colonial rule had imposed standard currencies and exchange rates, monitored by currency boards in the European capitals. This mode of operation was then taken up by national independent governments that created national currencies and national banks.

\section{Postcolonial Monies}

Postcolonial nations duplicated the model of their colonizers by issuing national currencies, under their own new names. Initially, national currencies remained pegged to the former colonial powers' currencies, but they were gradually replaced by independent currencies. The Nigerian naira replaced the Nigerian pound in 1972, after the Bank of England devalued the British pound, to which the Nigerian pound was pegged. In 1965, Ghana introduced a new currency not pegged to the sterling. ${ }^{56}$ The new Ghanaian currency, the cedi, meaning "cowry" in the Akan language, had a cowry shell represented on it. This was a way to connect the currency of independent Ghana with the precolonial past, when cowries were in use.

In the former British colonies, currency boards were replaced by national banks.

However, as Catherine Schenk shows, owing to the economic realities of the period, these central banks operated as currency boards "in all but names." They became government agencies devoted to financial matters and had more political than economic importance. ${ }^{57}$ Francophone Africa created two inclusive monetary zones for the franc CFA (Communauté Francaise Africaine) comprising eight countries in West Africa and six countries in Central Africa, whose currency value in exchange was pegged to the Franc and, later, to the euro, and was overseen by the French treasury. This points toward a tighter connection of the former French colonies to the former colonial power, that in part reflected the different forms of administration of the colonial period. 
The establishment of a new, national currency was an important expression of independence and sovereignty for the newly independent African states. This was reflected in the design of the new coins. In Ghana, the first of the British colonies in subSaharan Africa to obtain independence in 1957, the new coinage featured the image of the prime minister, Kwame Nkrumah. Nkrumah argued that with his image on the coin, Ghanaian people could be shown that "they are now really independent" through signs as well as words. ${ }^{58}$

The symbolism of currency design had multilayered meanings and can be interpreted as a statement of independence from colonial rule as well as a way to show the national specificities of African countries. Catherine Eagleton addresses the different political meanings associated with different currency designs in Kenya, Uganda, and Tanzania. The three former British colonies had the same currency during the colonial period and retained the name "shilling" for their independent ones. However, they used different designs and symbols. On one-shilling coins, Uganda used the crested crane (its national symbol), Tanzania the Uhuru (freedom) torch, and Kenya the Kenyan coat of arms. The Swahili inscriptions on the Tanzanian coins testified the policy of promotion of the Swahili language by President Julius Kambarage Nyerere. The English name shilling was replaced by the Swahili shilingi, and under the portrait of Nyerere himself, the inscription said rais wa kwanza, "first president." 59 The chosen design of the new currencies was the result of a complex set of relationships that had to promote the national identity and at the same time facilitate their circulation by using symbols that could be accepted by everyone.

The portraits of the leaders of anticolonial revolts on present-day currency notes are an example of how the symbolism on national money was and is connected to a shared identity and a shared history. The portraits of John Chilembwe on the Malawian kwacha, of Hendrik Witbooi on Namibian dollars, or of Nelson Mandela on South African rand are just a few examples in this direction. In 2005, new banknotes with the portraits of Jomo Kenyatta were issued in Kenya. However, after the electoral violence of 2007-2008, the new 2010 constitution provided that newly issued coins and notes should not have images of individuals on them, but only images that could represent a (unified) Kenya. ${ }^{60}$

In independent Africa, people maintained the precolonial inventiveness with objects that entered as money, by using long-lasting materials in spiritually oriented art, as distinct from simply decorative art. This theme comes forward from the precolonial past and is captured by certain studies of practices in the 20th century. Mary and Allen Roberts show clearly, in their illustrated book for a museum exhibit, how the Luba of Central Africa used cowries not only for decoration but also for symbolic purposes. They describe the lukasa, memory boards, which recorded royal histories through symbols engraved and attached to the boards: "beaded and shell emblems of Luba royalty," "building blocks of this mnemonic system." 61 Their illustrations show precisely placed cowries, at the topcenter of the lukasa, representing the center of the royal organization. ${ }^{62}$ 


\section{The Turn of the 21st Century}

Local and regional trade has not diminished in the present context of increased internationalization, and indeed it may well be that, with higher migration rates, political turbulence in some places, price fluctuations for imports and exports, and currency value instability, especially during the crisis preceding structural adjustment in the 1990s, the cross-border travel of currencies has intensified. In many places there developed informal exchange markets for foreign currencies, referred to and officially tracked under the rubric of the "parallel market." A record compiled from sources in 2017 offered the following summary for Nigeria naira: the interbank rate for the dollar was 305, for the British pound 377, and for the euro 323; the parallel market rate was 493 to the dollar, 595 to the British pound, and 506 to the euro. Clearly the local cost of currencies was much higher on the informal parallel market, thus making that market a source of profit. Through news tracking, the fluctuations in both the formal and parallel exchange markets can be followed. ${ }^{63}$ The collection entitled Money Struggles and City Life illustrates many contexts in which devaluation (1986-1996) was managed with difficulty in Ibadan, Nigeria. ${ }^{64}$

Janet MacGaffey and Rémy Bazenguissa-Manga have explored informal cross-border trades from the Congo, including, through particularly detailed research, the links to Paris. ${ }^{65}$ They include attention to a trade that has become important to the money economy of the 21st century, and often run as a cross-border trade within Africa, namely the trade in artisinally mined diamonds. Their subtitle includes the concept of being "on the margins of the law," and indeed attention to "margins in the multiplicity of African monies has been an old theme with yet more extensions into the present." 66 The rise of the whole range of the gemstone trade, coltan for the electronics industry, and links to globally spread African communities and trade networks place money and exchange rates at the center of this era of Africa's monetary history.

The descriptive sources on the marginally legal, but profitable, cross-border trades, and their relationship to fluctuating national currency values, is a theme particularly developed for Southern Africa. Zimbabwe's gemstone trade is analyzed in a collection edited by Richard Saunders and Tinashe Nyamunda. ${ }^{67}$ Nyamunda draws attention to the national mining organization's difficulty regulating the artisanal industry as "an economy on the margins," in part due to the higher prices that the informal buyers were willing to pay, "in foreign currency." 68 Jeremy Jones documents the rapid decline in the exchange rate of Zimbabwe's own currency at this time. ${ }^{69}$

This century's economy in Africa is in an era when remittances and trade abroad are increasingly important. There is an African trade community in China, and a Chinese trade community in certain African cities. ${ }^{70}$ Detailed study of African monies under present political and economic conditions will follow out the many "margins" in which the 
whole variety of participants, from official organizations, to local networks and communities, to individuals, operate and interact in contemporary Africa.

The use of cell-phone technology to make financial transactions, small payments, and money transfers has been developing in recent years in many African countries, testifying to the ability of African societies to innovate and incorporate change. The most successful example is M-Pesa in Kenya, which has fundamentally changed the way in which Kenyans use money. The service started in 2007 as a way to transfer money from the urban areas to the countryside and in this why they compensate for the absence of formal banking institutions in the rural areas. Since then, M-Pesa has grown enormously, and it is now used to pay for purchases, electricity and water bills, taxi rides, to obtain cash from ATMs, to obtain small loans, and so on. ${ }^{71}$ As Bill Maurer suggests, with mobile money "people are potentially setting in motion new media of exchange, methods of payment and stores of wealth and possibly measures of value." 72 The airtime trading by mobile users is a "user-driven innovation" that "produces an instability in and reversibility to the equation of airtime with state -issued currency." 73 This remaking of money by its users fosters financial inclusion and is another example of how multiplicity of currency use is a key theme in understanding money in Africa, in the past as well as in the present.

Alongside all these regulated national and regional systems, in the present globalizing economic world, with migration, remittances, and international commodity trade networks in the informal sector, and possibly through the channels of religious organizations and pilgrimages, African populations are again managing multiple currencies and shifting exchange rates, in yet another phase of economic history. Having done this already, over centuries, their present practices may reflect both certain elements from an archive of geographically and historically varied experience and practice, and an inventive frontier in the emergent globalizing economy of the present.

\section{Discussion of the Literature}

As a result of the regional variations, historical shifts, and recurrent engagements with non-African traders, the scholarly study of money in Africa has been a multi-disciplinary endeavor by historians, anthropologists, linguists, and archaeologists, aimed at very detailed empirical documentation of both single-money systems and multiple currencies in coexistence. Even though most of early anthropology was undertaken under colonial rule, ethnography developed attentive particularism, with the purpose of understanding people's systems in their own terms, and continuing to examine the functions of money in specific times, places, and materials, through active fieldwork and conceptual innovations.

Work in the field of African monetary history started to emerge during the late colonial period. Paul Bohannan's classic ethnography of exchange and investment among the Tiv of central Nigeria, where regional and local trade and exchange networks converged, 
placed the concept of "spheres of exchange" into the analysis of systems in which monies, such as brass rods, were applied only to specific categories of goods. In a system with "spheres of exchange," certain items could be valued in relation to one another in a consistent fashion, while other exchanges carried implicit moral problems. ${ }^{74}$ The increased use of colonial money, which was considered general-purpose money, shifted the system of "spheres of exchange" characterized by the circulation of special-purpose currencies. Bohannan defined the monetary transition of the colonial period as a "currency revolution." Later historians adopted Bohannan's "currency revolution" paradigm to analyze the introduction and acceptance of colonial money in West Africa and suggested that the introduction of colonial currencies represented a sort of rise of the money-economy moment in Africa, in which "modern money" facilitated exchange and the expansion of trade and replaced local, African currencies. ${ }^{75}$ The "currency revolution" interpretation has been criticized for not paying complete attention to the specificities of African monetary history and trade networks. In the collection entitled Money Matters: Instability, Values and Social Payments in the Modern History of West African Communities, Jane Guyer has pointed out that the term "revolution" suggests that one state of being was supplanted by another one, therefore assuming a victory of "modern" over "primitive" money. ${ }^{76}$ The contributors to the collection, including several African scholars, offer a wide range of new sources and terms, and close attention to specific places, eras of history, and social domains in order to capture the complexity of African currency changes over the longue durée.

Jean and John Comaroff have demonstrated that the introduction of colonial currencies among the Tswana was challenged by African conceptions of value in connection with different types of currency, that is, cattle, beads, and colonial money. ${ }^{77}$ Similarly, Ben Naanen has looked at how manillas and British currency coexisted in Nigeria and how this affected the lives of colonized people. Manillas, contrary to other local currencies, were redeemed only in 1948, and it was only then, according to Naanen, that the imposition of colonial state control was completed. ${ }^{78}$ Karin Pallaver has shown for Uganda that the monetary system that resulted from the introduction of colonial coins was not a replacement of the old currency system with a new one, but rather the result of convergence of different systems of value and monetary practices that incorporated precolonial African ways of handling, counting, and storing money. ${ }^{79}$ These studies have described the colonial monetization as an encounter of different regimes of value that gave rise to processes much more nuanced and complex than the replacement of precolonial currencies with coins and notes. Therefore, as Natalie Swanepoel points out, the colonial monetization was more a currency transition rather than a revolution. ${ }^{80}$

The internal counterpart of denominations, for different purposes, has been a recurrent and widespread but varying process in Africa. A conceptualization that arose with the European literature on Africa was the distinction between general-purpose and specialpurpose money. General-purpose money performs all the classical four functions of money: medium of exchange, means of payment, unit of account, and store of value. Special-purpose money only performs one of them. ${ }^{81}$ Paul Bohannan introduced this concept to Africanist anthropology and showed how Tiv precolonial currencies were

Page 19 of 29

PRINTED FROM the OXFORD RESEARCH ENCYCLOPEDIA, AFRICAN HISTORY (africanhistory.oxfordre.com). (c) Oxford University Press USA, 2016. All Rights Reserved. Personal use only; commercial use is strictly prohibited (for details see Privacy Policy and Legal Notice). 
special-purpose money, whereas colonial money was general-purpose money. ${ }^{82}$ Several scholars have, however, highlighted the limitations in distinguishing between generalpurpose and special-purpose currencies in African monetary history. For example, Philip Curtin pointed out that no currency is all purpose in any society, because no society makes payments for all the purposes that payments can be made for. ${ }^{83}$ Paul Lovejoy similarly argued that the question is not if West African currencies were all-purpose money that acted as mediums of exchange, common measures of value, stores of value, and standard of payment, but rather, the extent to which each met these requirements. ${ }^{84}$

James Webb was the first to discuss the problems with the application of neoclassical monetary concepts to the study of African currencies, arguing that there is a need to understand them in their own terms. Webb attempted to integrate African and Western moneys into a single theoretical framework, challenging the interpretation of the history of money in Africa as an "evolution" from "primitive" to "modern" money. ${ }^{85}$ A collection of ten papers by African and non-African scholars titled Money in Africa brought remarkable specificity, tangibility, and multi-disciplinarity in this direction, offering different case studies across centuries of local histories. The chapters adopted a flexible definition of money "which allows us to recognize the multiplicity of monies, and the overlapping and complimentary significance they have." ${ }^{86}$ Complementary and multiplicity are, in fact, keywords in understanding the history of money in Africa. Akinobu Kuroda has shown how the analysis of the circulation of complementary currencies-international, colonial, and local-in the Red Sea region can illuminate our understanding of the specificities of African monetary systems. ${ }^{87}$

In her book Marginal Gains: Monetary Transactions in Atlantic Africa, Jane Guyer underlines that current economic and anthropological approaches have enabled only a small part of the complexity of African monetary transactions and economies to be explored and understood. ${ }^{88}$ What is relevant in the study of the history of money in Africa is also the analysis of the symbolic and ritual values that currencies acquired once they left the exchange circuits. Important contributions in this direction come from the work of archaeologists, who have produced detailed data on various types of currency objects excavated in African sites and provided compelling interpretations of their currency use. These studies have shown the importance of the physical properties of money objects for how equivalences were established. ${ }^{89}$ Historical linguistics contributed to the field by analyzing the meanings of changes in currency use, through the words used to call and define different types of money. Andrea Seligman, for instance, showed how in the Rovuma region in 19th-century East Africa, brass became, from a prized and convertible currency, a symbol of elite power and fashion. ${ }^{90}$

Patterns and ongoing dynamics from the past, as understood from historical, ethnographic, archaeological, and linguistic sources, provide conceptual and empirical challenges of studying monetary multiplicity in the present that open new frontiers in the literature. 


\section{Primary Sources}

In the precolonial period, Europeans organized trade and scientific expeditions in various parts of Africa, whose success depended on the purchase and handling of the right types of commodity currencies. Their reports are therefore full of details on currency values and uses. Besides the large number of books and articles published by travelers, important archival records can be found in the archives of the geographical societies established in the 18th and 19th centuries, such as the Royal Geographical Society Archive (London) and the archives of the Société de Géographie (Bibliohèque Nationale de France, Paris). Missionaries in different parts of the African continent were among the first to provide firsthand evidence on the use of currencies by African people. Important collections of missionary documents are, among others, the Church Missionary Society Archive (University of Birmingham), the Council for World Mission Archive (School of Oriental and African Studies, London), and the White Fathers Archive (Rome). Essential sources are also museum collections of currency objects, which help to study the materiality of African currencies. Important collections are those of the British Museum (London), the Monnaie de Paris, the Pitt Rivers Museum (Oxford), and the Royal Museum of Central Africa (Tervuren). For the colonial period, information on money and currency can be obtained from the official documents of the European colonial powers available at metropolitan national archives (for example, National Archives, London; Archives Nationales d'Outre Mer, Aix-en-Provence; Bundesarchiv Abteilungen, Reichskolonialamt, Berlin) and African national archives (few examples are the Kenya National Archives; Tanzania National Archives; National Archives of Nigeria; Public Records and Archives Administration Department of Ghana, Accra; and National Archives of Cameroon, Yaoundé and Buea). Relevant information on currencies can be found in the archives of the banks that operated in Africa during the colonial period. For the British African colonies, some examples are the Bank of British West Africa Archive (London), Bank of England Archives (London), and Barclays Group Archives (Manchester). Finally, information on the design and production of banknotes and coins for the African colonies can be obtained from the records of the European mints (the records of the British Royal Mint are at the National Archives, London).

\section{Further Reading}

Bohannan, Paul. “The Impact of Money on an African Subsistence Economy.” The Journal of African Economic History 19, no. 4 (1959): 491-503.

Eagleton, Catherine. "Designing Change: Coins and the Creation of the New National Identities." In Cultures of Decolonisation: Transnational Productions and Practices, 194570. Edited by Ruth Craggs and Claire Wintle, 222-244. New York: Manchester University Press, 2016. 
Eagleton, Catherine, Harcourt Fuller, and John Perkins, eds. Money in Africa. London: British Museum Research Publications, 2009.

Guyer, Jane I. ed. Money Matters. Instability, Values and Social Payments in the Modern History of West African Communities. Portsmouth, NH: Heinemann, 1995.

Guyer, Jane I. Marginal Gains: Monetary Transactions in Atlantic Africa, Chicago: University of Chicago Press, 2004.

Hogendorn, Jan, and Marion Johnson. The Shell Money of the Slave Trade. Cambridge, UK: Cambridge University Press, 1986.

Hopkins, Anthony G. "The Currency Revolution in South-West Nigeria in the Late Nineteenth Century." Journal of the Historical Society of Nigeria 3, no. 3 (1966): 471-483.

Hopkins, Anthony G. "The Creation of a Colonial Monetary System: the Origins of the West African Currency Board.” African Historical Studies 3, no. 1 (1970): 101-132.

Kaler, Amy. “'When They See Money, They Think It's Life': Money, Modernity and Morality in Two Sites in Rural Malawi." Journal of Southern African Studies 32, no. 2 (2006): 335349 .

Kuroda, Akinobu. "The Maria Theresa Dollar in the Early Twentieth-Century Red Sea Regions: A Complementary Interface between Multiple Markets." Financial History Review 14, no. 1 (2007): 89-110.

Lovejoy, Paul. "Interregional Monetary Flows in the Precolonial Trade of Nigeria.” The Journal of African History 15, no. 4 (1974): 563-585.

Mwangi, Wambui. "The Lion, the Native and the Coffee Plant: Political Imagery and the Ambiguous Art of Currency Design in Colonial Kenya." Geopolitics 7, no. 1 (2002): 31-62.

Naanen, Ben. "Economy within an Economy: The Manilla Currency, Exchange Rate Instability and Social Conditions in South-Eastern Nigeria, 1900-48." The Journal of African History 34, no. 3 (1993): 425-446.

Ofonagoro, Walter I. "From Traditional to British Currency in Southern Nigeria: Analysis of a Currency Revolution.” Journal of Economic History 39, no. 3 (1979): 623-654.

Pallaver, Karin. “The African Native Has No Pocket': Monetary Practices and Currency Transitions in early Colonial Uganda." The Internatinal Journal of African Historical Studies 48, no. 3 (2015): 471-499.

Parry, Jonathan, and Maurice Bloch, eds. Money and the Morality of Exchange. Cambridge, UK: Cambridge University Press, 1989.

Saul, Mahir. "Money in Colonial Transition: Cowries and Francs in West Africa." American Anthropologist 106, no. 1 (2004): 71-84. 
Schenk, Catherine. "Monetary Institutions in Newly Independent Countries: the Experience of Malaya, Ghana and Nigeria in the 1950s." Financial History Review 4 (1997): 181-198.

Webb, James. "Toward the Comparative Study of Money: a Reconsideration of West African Currencies and Neoclassical Monetary Concepts." The International Journal of African Historical Studies 15, no. 3 (1982): 455-466.

Wynne-Jones, Stephanie, and Jeffrey Fleisher. "Coins in Context: Local Economy, Value and Practice on the East African Swahili Coast." Cambridge Archaeological Journal 22 (2012): 19-36.

\section{Notes:}

(1.) William C. Aitken, "Brass and Brass Manufacturers," in The Resources, Products, and Industrial History of Birmingham and the Midland Hardware District: A Series of Reports, Collected by the Local Industries Committee of the British Association at Birmingham in 1865, ed. Samuel Timmins (Birmingham, AL: Billing, Son and Co., 1866), 274.

(2.) Edward W. Bovill, The Golden Trade of the Moors (London: Oxford University Press, 1958), 131.

(3.) Ghislaine Lydon, On Trans-Saharan Trails. Islamic Law, Trade networks, and CrossCultural Exchange in Nineteenth-Century Western Africa (Cambridge, UK: Cambridge University Press, 2009), 250.

(4.) Quoted in Bovill, The Golden Trade of the Moors, 161.

(5.) Lydon, On Trans-Saharan Trails, 252.

(6.) Jan Hogendorn and Marion Johnson, The Shell Money of the Slave Trade (Cambridge, UK: Cambridge University Press, 1986), 18.

(7.) Hogendorn and Johnson, The Shell Money, 5-6.

(8.) Jan Vansina, The Children of Woot: a History of the Kuba Peoples (Madison: University of Wisconsin Press, 1978), 189.

(9.) Kwame Arhin, "The Pressure of Cash and Its Political Consequences in Asante in the Colonial Period, 1900-1940," Journal of African Studies 3, no. 4 (1976): 453-468.

(10.) Timothy F. Garrard, Akan Weights and the Gold Trade (London: Longman, 1980).

(11.) Kwame Arhin, "Gold Mining and Trading among the Ashanti of Ghana," Journal des Africanistes 48, no. 1 (1978): 89, 94, 97. 
(12.) Kwame Arhin, "Monetization and the Asante State," in Money Matters. Instability, Values and Social Payments in the Modern History of West African Communities, ed. Jane I. Guyer (Portsmouth, NH: Heinemann, 1995), 97-110.

(13.) E. Bakaluba, Buganda N’ensimba Zaayo (Kampala: Eagle Press, 1951), 1.

(14.) Lucy Mair, An African People in the Twentieth Century (London: Routledge, 1934), 133.

(15.) John Tosh, "The Northern Interlacustrine Region," in Pre-colonial African Trade: Essays on Trade in Eastern and Central Africa, eds. Richard Gray and David Birmingham (London: Oxford University Press, 1970), 107; and John Roscoe, The Baganda: the Native Customs and Beliefs (London: Macmillan, 1911), 269.

(16.) Bakaluba, Buganda N’ensimba Zaayo, 4.

(17.) Paul Lovejoy, "Interregional Monetary Flows in the Precolonial Trade of Nigeria," in The Journal of African History 15, no. 4 (1974): 564; and Jane Guyer, "Introduction: The Currency Interface and Its Dynamics," in Money Matters: Instability, Values and Social Payments in the Modern History of West African Communities, ed. Jane Guyer (Portsmouth, NH: Heinemann, 1995), 15.

(18.) Richard Pankhurst, An Introduction to the Economic History of Ethiopia (London: Lalibela House, 1961).

(19.) John M. Perkins et al., “A Deposit of Kilwa-Type Coins from Songo Mnara, Tanzania,” Azania: Archaeological Research in Africa 49, no. 4 (2014): 102-116; and Stephanie Wynne-Jones and Jeffrey Fleisher, "Coins and Other Currencies on the Swahili Coast," in The Archaeology of Money, eds. Haselgrove and Krmnicek (Leicester, UK: Leicester University Press, 2016): 115-136.

(20.) Greville S. P. Freeman-Grenville, "Coin Finds and Their Significance for East African Chronology," Numismatic Chronicle (1971): 283-301; Neville Chittick, "On the Chronology and Coinage of the Sultans of Kilwa," Numismatic Chronicle 13 (1973): 193200; John Middleton, "Merchants: An Essay in Historiographical Ethnography," Journal of the Royal Anthropological Institute 9 (2003): 509-526; and Stephanie Wynne-Jones and Jeffrey Fleisher, "Coins in Context: Local Economy, Value and Practice on the East African Swahili Coast," Cambridge Archaeological Journal 22 (2012): 19-36.

(21.) Karin Pallaver, "Currencies of the Swahili World," in The Swahili World, eds. Stephanie Wynne-Jones and Adria LaViolette (New York: Routledge, 2018), 447-457.

(22.) Karl Polanyi, "Sortings and 'Ounce Trade' in the West African Slave Trade," The Journal of African History 5, no. 3 (1964); and Marion Johnson, "The Ounce in EighteenthCentury West African Trade," The Journal of African History 7, no. 2 (1966): 197-214.

(23.) Johnson, “The Ounce Trade," 208. 
(24.) Hogendorn and Johnson, The Shell Money, 109.

(25.) Jan Hogendorn and Henry A. Gemery, "Continuity in West African Monetary History? An Outline of Monetary Development," African Economic History 17 (1988): 127-146.

(26.) Claudia Zaslavsky, Africa Counts: Number and Pattern in African Cultures (Boston: Prindle, Weber and Schmidt, 1973), 73.

(27.) Karin Pallaver, "The African Native Has No Pocket': Monetary Practices and Currency Transitions in Early Colonial Uganda," The Internatinal Journal of African Historical Studies 48, no. 3 (2015): 471-499.

(28.) Hogendorn and Johnson, The Shell Money, 11.

(29.) Toby Green, "Africa and the Price Revolution: Currency Imports and Socioeconomic Change in West and West-Central Africa During the Seventeenth Century," The Journal of African History 57, no. 1 (2016): 15.

(30.) Robin Law, "Cowries, Gold and Dollars. Exchange Rate Instability and Domestic Price Inflation in Dahomey in the Eighteenth and Nineteenth Centuries," in Money Matters: Instability, Values and Social Payments in the Modern History of West African Communities, ed. Jane I. Guyer (Portsmouth, NH: Heinemann, 1995), 53-74.

(31.) Lovejoy, “Interregional Monetary Flows,” 569.

(32.) Jonathan Glassman, Feasts and Riot. Revelry, Rebellion, and Popular Consciousness on the Swahili Coast, 1856-1888 (Portsmouth, NH: Heinemann, 1995), 36; and Anthony G. Hopkins, An Economic History of West Africa (London: Longman, 1973), 67.

(33.) Stephen Rockel, Carriers of Culture. Labor on the Road in Nineteenth-century East Africa (Portsmouth, NH: Heinemann, 2006), 211-228.

(34.) Karin Pallaver, "A Recognized Currency in Beads." Glass Beads as Money in Nineteenth-century East Africa: The Central Caravan Road," in Money in Africa, eds. Catherine Eagleton, Harcourt Fuller, and John Perkins (London: British Museum Research Publications, 2009), 20-29.

(35.) Walter I. Ofonagoro, "The Currency Revolution in Southern Nigeria 1880-1948," Occasional Paper No. 14. James Coleman African Studies Center, UCLA (1976): 6.

(36.) Walter I. Ofonagoro, "From Traditional to British Currency in Southern Nigeria: Analysis of a Currency Revolution," Journal of Economic History 39, no. 3 (1979): 648.

(37.) Akinobu Kuroda, "What Is the Complementarity among monies? An Introductory Note," in Financial History Review 15, no. 1 (2008): 7; and Akinobu Kuroda, "The Maria Theresa Dollar in the Early Twentieth-Century Red Sea Regions: A Complementary Interface between Multiple Markets," Financial History Review 14, no. 1 (2007): 89-110. 
(38.) Eric Helleiner, "The Monetary Dimensions of Colonialism: Why Imperial Powers Created Currency Blocks?," Geopolitics 7, no. 1 (2002): 5-30.

(39.) Ben Naanen, "Economy within an Economy: The Manilla Currency, Exchange Rate Instability and Social Conditions in South-Eastern Nigeria, 1900-48," The Journal of African History 34, no. 3 (1993): 427.

(40.) Naanen “Economy within an Economy," 446.

(41.) Walter I. Ofonagoro, "From Traditional to British Currency," 652.

(42.) Ofonagoro, "From Traditional to British Currency," 654.

(43.) Pallaver, "The African Native."

(44.) Mahir Saul, "Money in Colonial Transition: Cowries and Francs in West Africa," American Anthropologist 106, no. 1 (2004): 71, 80.

(45.) Pallaver, "The African Native."

(46.) James Fernandez, Bwiti: An Ethnography of the Religious Imagination in Africa (Princeton, NJ: Princeton University Press, 1982).

(47.) Fernandez, Bwiti, 132-135.

(48.) Jean Comaroff and John Comaroff, "Colonizing Currencies. Beasts, Banknotes, and the Colour of Money in South Africa," in Commodification, Things, Agency and Identity (The Social Life of Things Revisited), eds. Wim van Binsbergen and Pieter Geschiere (Leiden, The Netherlands: Brill, 2005).

(49.) Marc Michel, Les Africains et la Grande Guerre. L'appel à l'Afrique (1914-1918) (Paris: Karthala, 2003), 167; Elizabeth Wrangham, Ghana During the First World War: The Colonial Administration of Sir Hugh Clifford (Durham: University of North Carolina Press, 2013), 137; David Killingray, "Repercussions of World War I in the Gold Coast," The Journal of African History 1, no. 1 (1978): 45; and Akinjide Osuntokun, Nigeria in the First World War (London: Longman, 1979): 43.

(50.) Wambui Mwangi, "The Lion, the Native and the Coffee Plant: Political Imagery and the Ambiguous Art of Currency Design in Colonial Kenya," Geopolitics 7, no. 1 (2002): 49.

(51.) Amy Kaler, “'When They See Money, They Think It’s Life’: Money, Modernity and Morality in Two Sites in Rural Malawi," Journal of Southern African Studies 32, no. 2 (2006): 335-349.

(52.) Toyin Falola and Akanmu Adebayo, Culture, Politics and Money among the Yoruba (New Brunswick: Transaction Publishers, 2000): 51-65. 
(53.) Toyin Falola, "Currency Instability and Informal Credit Institutions in Colonial Western Nigeria," in Money Matters: Instability, Values and Social Payments in the Modern History of West African Communities, ed. Jane I. Guyer (Portsmouth, NH: Heinemann, 1995), 179.

(54.) See cases in Jane I. Guyer, ed., Feeding African Cities: Studies in Regional Social History (Manchester, UK: Manchester University Press, 1987).

(55.) Wambui Mwangi, "Of Coins and Conquest: The East African Currency Board, the Rupee Crisis and the Problem of Colonialism in the East African Protectorate," Comparative Studies in Society and History 4, no. 4 (2001): 777.

(56.) Catherine Schenk, "Monetary Institutions in Newly Independent Countries: The Experience of Malaya, Ghana and Nigeria in the 1950s," Financial History Review 4 (1997): 195.

(57.) Schenk, “Monetary Institutions in Newly Independent Countries,” 195.

(58.) Catherine Eagleton, "Designing Change: Coins and the Creation of the New National Identities," in Cultures of Decolonisation: Transnational Productions and Practices, 19451970, eds. Ruth Craggs and Claire Wintle (New York: Manchester University Press), 222.

(59.) Eagleton, “Designing Change,” 228.

(60.) Eagleton, “Designing Change,” 239.

(61.) Mary Nooter Roberts and Allen F. Roberts, Visions of Africa: Luba (Paris: Five Continents Press, 2007).

(62.) See Roberts and Roberts, Visions of Africa, 141, for the illustration of an example of lukasa.

(63.) On Nigeria, see for example, The Central Bank Exchange Rates and DAWN May 17th: 2017. Naira stable at N385/\$ as CBN injects $\$ 453.3 \mathrm{~m}$.

(64.) Jane I. Guyer, LaRay Denzer, and Adigun Agbaje, eds., Money Struggles and City Life: Devaluation in Ibadan and Other Urban Centers in Southern Nigeria 1986-1996 (Portsmouth, NH: Heinemann, 2002).

(65.) Janet MacGaffey and Rémy Bazenguissa-Ganga, Congo-Paris: Transnational Traders on the Margins of the Law (Oxford: James Currey, 2000).

(66.) Jane I. Guyer, Marginal Gains: Monetary Transactions in Atlantic Africa (Chicago: University of Chicago Press, 2004).

(67.) Richard Saunders and Tinashe Nyamunda, eds., Facets of Power: Politics, Profits and People in the Making of Zimbabwe's Blood Diamonds (Harare: Weaver Press, 2016). 
(68.) Tinashe Nyamunda "Free-for-All"? Artisanal Diamond Mining and Economic Redistribution on the Edges of the State, 2006-2008," in Facets of Power: Politics, Profits and People in the Making of Zimbabwe's Blood Diamonds, eds. Richard Saunders and Tinashe Nyamunda (Harare: Weaver Press, 2016), 116-117.

(69.) Jeremy L. Jones, “'Nothing Is Straight in Zimbabwe': The Rise of the Kukiya-kiya Economy 2000-2008," Journal of Southern African Studies 36, no. 2 (2010): 285-299.

(70.) Adams Bodomo, Africans in China: A Sociocultural Study and Its Implications on Africa-China Relations (Amherst, NY: Cambria Press, 2012).

(71.) Anja Bengelstorff, “A Global Success from Kenya” (Credit Suisse, 2015).

(72.) Bill Mauer, "Mobile Money: Communication, Consumption and Change in the Payments Space," Journal of Development Studies 48, no. 5 (2012): 601.

(73.) Maurer, “Mobile Money," 592.

(74.) Paul Bohannan, "The Impact of Money on an African Subsistence Economy," The Journal of African Economic History 19, no. 4 (1959): 501.

(75.) See, for example, Hopkins "The Currency Revolution"; and Ofonagoro, "From Traditional to British Currency in Southern Nigeria: Analysis of a Currency Revolution."

(76.) Guyer, "Introduction: The Currency Interface and Its Dynamics," in Money Matters, ed. Guyer, 1-2.

(77.) Comaroff and Comaroff, “Colonizing Currencies,” 145.

(78.) Naanen, "Economy within an Economy."

(79.) Pallaver, "The African native has no Pocket."

(80.) Natalie Swanepoel, "Small Change: Cowries, Coins, and the Currency Transition in the Northern Territories of Ghana," in Materializing Colonial Encounters: Archaeologies of African Experience, ed. François G. Richard (New York: Spinger, 2015), 41-69.

(81.) Karl Polanyi, "The Economy as an Instituted Process," in Trade and Markets in the Early Empires, eds. Karl Polanyi, Conrad M. Arensberg, and Harry W. Pearson (Glencoe, IL: Free Press, 1957), 243-270.

(82.) Paul Bohannan, "The Impact of Money."

(83.) Philip D. Curtin, Economic Change in Precolonial Africa: Senegambia in the Era of the Slave Trade (Madison: University of Wisconsin Press, 1975), 235.

(84.) Lovejoy, "Interregional Monetary Flows," 564. 
(85.) James Webb, "Toward the Comparative Study of Money: A Reconsideration of West African Currencies and Neoclassical Primitive Money," in The International Journal of African Historical Studies 15, no. 3 (1982): 455-466. Early works on African money defined it as "primitive"; see, for example, Mary Alison H. Quiggin, A Survey of Primitive Money: The Beginning of Currency (London: Methuen and Co., 1949); and Paul Einzig, Primitive Monery in its Ethnological, Historical and Economic Aspects (London: Eyre and Spottiswoode, 1949).

(86.) Catherine Eagleton, "Introduction," in Money in Africa, eds. Catherine Eagleton, Harcourt Fuller, and John Perkins (London: British Museum Research Publications, 2009).

(87.) Kuroda, "The Maria Theresa Dollar in the Early Twentieth-Century Red Sea Regions."

(88.) Guyer, Marginal Gains.

(89.) Swanepoel, "Small Change"; and Wynne-Jones and Fleisher, "Coins in Context."

(90.) Andrea F. Seligman, "Wealth Not by Any Other Name: Inland African Material Aesthetics in Expanding Commercial Times, c. 16th-20th Centuries," International Journal of African Historical Studies 48, no. 3 (2015): 449-469.

\section{Jane I. Guyer}

Department of Anthropology, Johns Hopkins University

\section{Karin Pallaver}

Department of History, University of Bologna

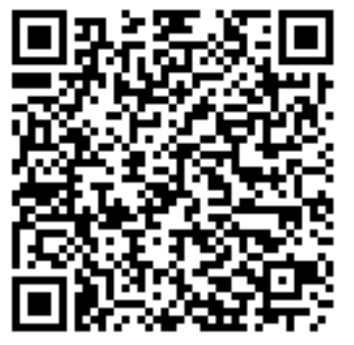

